\title{
La prensa clandestina en la insurrección cubana (1953-1958): mismo objetivo, diferentes tácticas
}

\author{
The Clandestine Press in the Cuban Insurrection (1953-1958): \\ Same Objective, Different Tactics
}

\author{
Patricia Calvo González*
}

\begin{abstract}
Resumen: Con este trabajo se pretende incidir en los órganos de comunicación que se produjeron durante la insurrección cubana (1953-1958) en condiciones de clandestinidad, dada la coyuntura de censura que existía en la isla durante la época referida. Se centrará la atención en la prensa del Movimiento 26 de Julio (M26J) y del Directorio Revolucionario (DR), en un estudio comparativo que permita identificar los objetivos de cada grupo, así como las tácticas que siguieron para alcanzarlos en base a lo plasmado en sus boletines. Para ello se realizará un análisis de sus principales publicaciones (Revolución y Sierra Maestra para el M26J y Alma Mater y 13 de Marzo para el DR) lo que permitirá identificar esos puntos de conexión y de diferencia.
\end{abstract}

Palabras clave: prensa clandestina, Revolución Cubana, insurrección, Movimiento 26 de Julio, Directorio Revolucionario

\begin{abstract}
This work deals with the media that were developed during the Cuban Insurrection (1953-1958) in clandestine conditions, due to the situation of censorship that existed in the island in the referred date. The focus will be on the press of the 26th of July Movement (M26J) and the Revolutionary Directory (DR), in a comparative study that allows to identify the objectives of each group as well as the tactics that followed to reach them based on what is reflected in their bulletins. An analysis of its main publications has been made (Revolución and Sierra Maestra for M26J, Alma Mater and 13 de Marzo for DR), which will allow us to identify the points of connection and difference.
\end{abstract}

Keywords: clandestine press, Cuba Revolution, insurrection, 26th of July Movement, Revolutionary Directory

\footnotetext{
* Española, Doctora en Historia Contemporánea e Investigadora Postdoctoral I2C Xunta de Galicia de la Universidad de Santiago de Compostela (Galicia, España).patricia.calvo@usc.es
} 


\section{Introducción}

La prensa clandestina durante la insurrección cubana tuvo un significativo papel teniendo en cuenta que desde que Fulgencio Batista dio el golpe de estado el 10 de marzo de 1952, la libertad de prensa fue congelada en diversos momentos, dando paso a la censura y consecuentemente solo apareciendo en los medios de comunicación cubanos la versión de la oficialidad ${ }^{1}$. Es por ello que los grupos opositores dedicaron parte de su empeño a realizar publicaciones para poder difundir todo aquello relacionado con la lucha contra Batista que no se podía incluir en la prensa generalista. De este modo, el objetivo de estas líneas es incidir en el contenido de los órganos y boletines de dos de los grupos más significativos en la lucha insurreccional cubana -Movimiento 26 de Julio (M26J) y Directorio Revolucionario (DR) - para dirimir los puntos de encuentro y de diferencia de ambas organizaciones, fundamentalmente en los planos ideológico, organizacional y de acción.

La contextualización histórica de la oposición cubana en esta etapa se caracteriza primeramente por no contar con un relato lineal, en ella se entrecruzan diversos grupos políticos y armados así como diferentes tácticas a seguir para alcanzar el fin último, que era derrocar a Batista y su régimen impuesto ${ }^{2}$. Inmediatamente después al golpe de estado (10 de marzo de 1952), hubo en la sociedad cubana un cierto beneplácito hacia el nuevo sistema y la postura de los partidos tradicionales fue plegarse al mismo ${ }^{3}$. La labor de Batista durante la década de los treinta prestó credibilidad a sus palabras, orientadas a promesas de fortalecimiento de la economía y de garantías de seguridad de las vidas y las propiedades de los cubanos ${ }^{4}$. Además, Estados Unidos y los gobiernos latinoamericanos mostraron también complacencia ante la política instaurada ${ }^{5}$. No obstante, Batista comenzó pronto a tener problemas casi a diario con la oposición, siendo el principal foco de resistencia la Universidad de La Habana, donde la Federación Estudiantil Universitaria (FEU) organizó diversas manifestaciones y estableció planes conspirativos en contra del gobierno. Con el paso de los días fue ganando fuerza la idea de que el régimen solo podía ser depuesto por la vía armada, línea que seguirían diferentes grupos, siendo el ataque al Moncada el 26 de julio de 1953 el acto que marcaría un punto de inflexión respecto de la movilización social ${ }^{6}$.

Pero hasta el año 1955, tras el fracaso del asalto y la aniquilación o encarcelamiento de los involucrados en el mismo, no daría comienzo una nueva estrategia opositora a Batista. Los partidos tradicionales (Auténtico y Ortodoxo) se reagruparon y los estudiantes universitarios eligieron una nueva dirección y radicalizaron su postura ${ }^{7}$. En este mismo año

\footnotetext{
${ }^{1}$ Patricia Calvo González, «Visiones desde dentro. La insurrección cubana a través del Diario de la Marina y Bohemia (1956-1958)», História (São Paulo), v.33, n.2, jul./dic. 2014a, 346-379.

${ }^{2}$ Ramón Bonachea y Marta San Martín, The Cuban Insurrection, 1952-1959, New Jersey, Transaction Books, 1974.

${ }^{3}$ Óscar Zanetti, Historia mínima de Cuba, México, El Colegio de México, 2013, 257.

${ }^{4}$ Hugh Thomas, Cuba. La lucha por la libertad, Barcelona, Grijalbo, 1974, 1025.

${ }^{5}$ Bonachea y San Martín, op. cit., 1.

${ }^{6}$ Marifeli Pérez-Stable, La revolución cubana. Orígenes, desarrollo y legado, Madrid, Colibrí, 1998.

${ }^{7}$ Pérez-Stable, op. cit., 103.
} 
se constituyó la Sociedad de Amigos de la República (SAR), que pretendía un diálogo cívico y celebrar nuevas elecciones para legalizar el gobierno cubano. Batista aparentemente aceptó la invitación, pero no estaba dispuesto a celebrar comicios hasta 1958, por lo que la lucha armada como única forma de hacerle frente al gobierno salió reforzada ${ }^{8}$. A partir de este momento, los sabotajes y la violencia en general empezaron a hacerse más recurrentes y surgieron en esta época las dos organizaciones más importantes respecto de la lucha insurreccional: el Movimiento 26 de Julio (M26J) y el Directorio Revolucionario (DR). El DR basaba su estrategia en una huelga general revolucionaria y más tarde se concentró en desarrollar un único golpe para poner fin al régimen: el asesinato de Batista. Por su parte, el M26J en un principio también desarrolló su táctica en torno a la huelga general revolucionaria, pero tras el fracaso de esta en abril de 1958, centró todos sus esfuerzos y recursos en un enfrentamiento en contra del Ejército regular, la institución en la que Batista cimentó su poder desde su primera aparición en la política cubana9.

De forma general, se puede hablar de dos etapas dentro de la etapa insurreccional cubana en función de las acciones de la oposición: una primera, con la organización, crecimiento y equipamiento de un movimiento clandestino urbano, y una segunda con la formación, desarrollo y mantenimiento de una guerrilla rural ${ }^{10}$. La primera etapa comprende a su vez tres fases: la primera de formación, hasta 1955; la segunda de ofensiva, hasta abril de 1958; y una tercera de apoyo-defensiva, tras fallar en sus acciones de ataque al Palacio Presidencial (13 de marzo de 1957) y huelga general (9 de abril de 1958). A partir de ese momento, los efectivos en las ciudades quedaron expuestos a la represión, causando un gran descalabro en las filas del movimiento urbano, tanto en el DR como en el M26J, que incluyó la muerte de dos de sus principales dirigentes: José Antonio Echeverría y Frank País. Los grupos de las ciudades perdieron así cierta iniciativa e independencia y pasaron a intentar sobrevivir y a prestar su apoyo al Ejército Rebelde, que a partir de mediados de 1958 concentró toda la autoridad militar y política ${ }^{11}$.

La segunda etapa estuvo protagonizada por la guerrilla rural, y a su vez también se compuso dos fases. La primera, que coexistió con la ofensiva urbana, se caracterizó por la acción de pequeños grupos guerrilleros en contra del Ejército. Los objetivos eran simples: explotar las ventajas del terreno (Sierra Maestra y Sierra del Escambray), mantener la iniciativa sobre las tropas regulares y sobrevivir. Desde el desembarco del Granma (en diciembre de 1956) y el ataque del Uvero (mayo de 1957) hasta la apertura de un segundo frente en el norte de la provincia de Oriente (marzo de 1958), la estrategia de la guerrilla se centró en realizar rápidos ataques con retiradas igual de rápidas. Asimismo, cada repliegue se combinaba con emboscadas a las postas militares en la Sierra Maestra, que poco a poco se fueron abandonando y se trasladaron a áreas marginales adyacentes, lo que otorgaba mayor control territorial a los rebeldes ${ }^{12}$.

\footnotetext{
${ }^{8}$ Jorge Renato Ibarra Guitart, El fracaso de los moderados en Cuba. Las alternativas reformistas de 1957 a 1958, La Habana, Editora Política, 2000.

${ }^{9}$ Thomas, op. cit., 901-ss.

${ }^{10}$ Bonachea y San Martín, op. cit., 4.

${ }^{11}$ Pérez-Stable, op. cit., 263.

12 Bonachea y San Martín, op. cit., 7-8.
} 
El inicio de la siguiente fase se dio tras el fracaso de la huelga de abril de 1958 que, como ya se ha indicado, hizo que se concentraran los esfuerzos en la guerrilla. Batista preparó una ofensiva contra la Sierra Maestra, pero las expectativas de aplastar la rebelión pronto se vieron desvirtuadas. Las montañas orientales se vieron cercadas por más de diez mil hombres y se lanzaron columnas para aplastar al bastión rebelde. Pero la guerrilla, a pesar de su inferioridad numérica y armamentística, supo moverse de manera que pudo enfrentarse por separado y con ventaja a los batallones. Después de sufrir cientos de bajas en unos dos meses, el Ejército emprendió la retirada, dejando atrás armamento y a la Sierra Maestra convertida en «territorio libre». Las columnas guerrilleras emprendieron entonces su descenso de las montañas y, tras la toma de Santa Clara a finales de 1958, la isla quedó cortada en dos. Incapaz de revertir las acciones, Batista huyó en la madrugada del 1 de enero de 1959. Los rebeldes siguieron avanzando sobre las ciudades y convocaron una huelga general. La revolución había triunfado ${ }^{13}$.

\section{Un acercamiento teórico-metodológico al análisis de la prensa clandestina}

El estudio de la prensa clandestina comienza por tener en cuenta su enmarcamiento en la concepción de propaganda, término con diferentes matices, no siempre en positivo, sobre todo desde su utilización institucionalizada por parte del nazismo ${ }^{14}$. De forma sintética, se entiende la propaganda como la expresión de una opinión o una acción por individuos o grupos, deliberadamente orientada a influir en opiniones y acciones de otros individuos o grupos para unos fines predeterminados ${ }^{15}$. Asimismo, la propaganda, en el terreno de la comunicación social, consiste en un proceso de diseminación de ideas a través de múltiples canales con la finalidad de promover en el grupo al que se dirige los objetivos del emisor no necesariamente favorables al receptor: «Implica, pues, un proceso de

\footnotetext{
${ }^{13}$ Pérez-Stable, op. cit., 264-265; Bonachea y San Martín, op. cit., 6. Para un relato más detallado de las acciones de Sierra Maestra, véase Ernesto Guevara, Pasajes de la guerra revolucionaria, La Habana, Ed. Política, 2003 [1963]; Carlos Franqui, Diario de la Revolución Cubana, Barcelona, Ediciones R. Torres, 1976; FAR (Fuerzas Armadas Revolucionarias de Cuba), De Tuxpan a La Plata, La Habana, Ed. Orbe, 1981; Roberto Pérez Rivero, La guerra de liberación nacional, Santiago de Cuba, Ed. Oriente, 2006; Marta Verónica Álvarez Mola y Sergio Ravelo López, En combate por la esperanza, La Habana, Ed. Política, 2006, y La victoria de la esperanza, La Habana, Ed. Política, 2009; Pedro Álvarez Tabío, La conquista de la esperanza. Diario de campaña Ernesto Che Guevara y Raúl Castro Ruz 2 de diciembre de $1956-19$ de febrero de 1957, La Habana, Ed. Verde Olivo, 2005, y Diario de la guerra, La Habana, Oficina de Publicaciones Consejo Estado, 2010; Fidel Castro, La victoria estratégica. Por todos los caminos de la Sierra y La contraofensiva estratégica. De la Sierra Maestra a Santiago de Cuba, La Habana, Oficina de Publicaciones del Consejo de Estado, 2010.

14 «[...] la violencia simbólica de la propaganda del Tercer Reich ha tenido ecos muy considerables en la comunicación occidental; uno de esos ecos ha sido, de hecho, la connotación negativa adquirida por el propio vocablo propaganda y su sustitución por eufemismos como publicidad política, comunicación política, etc.». Antonio Pineda Cachero, «Orígenes histórico-conceptuales de la teoría de la propaganda nazi», Revista Historia y Comunicación Social, n 12, 2007, 154.

${ }^{15}$ Edwards [1938] en Alejandro Pizarroso Quintero, Historia de la propaganda. Notas para un estudio de la propaganda política y de guerra. Universidad Complutense de Madrid, 1993, 28.
} 
información y un proceso de persuasión» ${ }^{16}$. Se trata, por tanto, de una actividad que pretende inducir a otros a comportarse de una manera determinada, distinta a la conducta que hubiesen adoptado sin su existencia ${ }^{17}$.

En el caso objeto de análisis, no se puede obviar que la propaganda está ligada a un contexto de lucha armada, un nexo denominado por la escuela anglosajona como Psychological Warfare (guerra psicológica): «El uso planificado de propaganda y otras acciones orientadas a generar opiniones, emociones, actitudes y comportamientos en grupos extranjeros, enemigos, neutrales y amigos, de tal modo que apoyen el cumplimiento de fines y objetivos nacionales» ${ }^{18}$. A esta definición, Pizarroso añade que la propaganda de guerra no se dirige solamente hacia el exterior, sino también hacia el interior, «tanto a la propia población civil que sostiene el esfuerzo de la guerra como a los miembros de los ejércitos que la llevan a cabo» ${ }^{19}$. Tenemos así un instrumento de persuasión que se desarrolla en un entorno particular orientado a diferentes públicos bajo un mismo fin. De hecho, en estudios sobre la estrategia militar desarrollada por el Ejército Rebelde, se ha mencionado esta herramienta como parte de la estrategia: «No limitar el papel de la propaganda a nuestras fuerzas, sino que abarcara el trabajo político-ideológico con el enemigo (guerra psicológica)» ${ }^{20}$.

La prensa clandestina además, desde el punto de vista teórico, tiene una serie de funciones generales: informativa, doctrinal, agitativo-solidaria y organizativa-militante ${ }^{21}$. De todas ellas, destaca su función informativa en tres niveles: 1) informativa directa, que se contrapone a la falta de información en la prensa generalista; 2) informativa esclarecedora, en el sentido de romper el cerco de la «verdad oficial»; y 3) informativa amplificadora, ya que en sus páginas aparecen conflictos sociales y políticos ausentes en los medios convencionales. A esta función estrictamente periodística, hay que sumarle, como característica general de la prensa clandestina, su vocación doctrinal. Dicha tarea implica en algunos casos no limitarse a la difusión de marcos teóricos generales, objetivos y programas políticos, sino que tendrá su continuidad mediante el debate en una dimensión interna: la propia organización como actor político. Junto a estos aspectos informativos y doctrinales se encuentra la función agitativo-solidaria, que supone la expresión de la vocación movilizadora presente en cualquier prensa política; y la función organizativomilitante, que hace referencia al papel que los órganos clandestinos ejercen como

\footnotetext{
${ }^{16}$ Alejandro Pizarroso Quintero, «La historia de la propaganda: una aproximación metodológica», Historia y Comunicación Social, $\mathrm{n}^{\circ}$ 4, 1999, 147.

${ }^{17}$ Ingrid Schulze, El poder de la propaganda en las guerras del siglo XIX, Madrid, Arco Libros, $2001,7$.

${ }^{18}$ Daugherty en Pizarroso Quintero, op. cit. 1993, 34. Véase también Giuseppe Gagliano, Psychological warfare, social movements and ecoterrorism, CESTUDEC (Centro Studi Strategici Carlo de Cristoforis), 2012.

${ }^{19}$ Pizarroso Quintero, op. cit. 1993, 34.

${ }^{20}$ Pérez Rivero, op. cit., 21.

${ }^{21}$ Tomamos aquí los apuntes sobre los órganos clandestinos elaborados por Ibarra (Pedro Ibarra, «La prensa clandestina en Euskadi bajo el franquismo», La prensa de los siglos XIX y XX. Metodología, ideología e información. Aspectos económicos y tecnológicos, Bilbao, Universidad del País Vasco, 1986, 689-692.), que a su vez retoma el análisis funcional de este tipo de comunicación elaborado por Bassets y Bastardes (Lluís Bassets y Enric Bastardes, «La prensa clandestina en Catalunya: una reflexión metodológica», Alternativas populares a las comunicaciones de masas, Madrid, CIS, 1979, 155-175).
} 
instrumento de cohesión del grupo, su papel en la formación y dinámica de la propia militancia, y su dimensión organizativa allí donde las estructuras del grupo no podían llegar, como por ejemplo, en aquellos ámbitos geográficos donde la organización no tenía presencia o esta era poco estable.

Estas funciones derivan a su vez en jerarquías de análisis del contenido presente en la prensa clandestina ${ }^{22}$, metodología ya aplicada por Cortina Orero en su estudio acerca de la comunicación insurgente en el caso salvadoreño ${ }^{23}$, que se toma como referencia para este análisis de los órganos del DR y del M26J. Las jerarquías establecidas y señaladas de forma porcentual, en base a los conceptos propuestos por Ibarra, serían: 1) información; 2) debate; 3) coyuntura; 4) cultura partidaria; 5) denuncia; 6) comunicados/partes; 7) organizaciónmovilización; 8) formación; y 9) doctrina. El objetivo de dicho análisis es definir cuáles de las categorías propuestas adquirieron mayor peso en la prensa de los grupos armados objeto de estudio y constatar qué aspectos primaron en la propaganda de cada uno de ellos.

Como unidad de análisis, una vez revisadas las publicaciones, se ha seguido un doble criterio, equiparable por la entidad que representan ambas opciones en la visión general de las ediciones. Tenemos así, por un lado, el artículo o pieza escrita en torno a un titular y, por otro, diversas notas agrupadas bajo un título general. Nos apartamos de este modo de los patrones seguidos para un análisis tipo de la prensa generalista, donde la ubicación y el número de columnas influyen directamente en la percepción de la noticia ${ }^{24}$. En este caso, estamos ante publicaciones de carácter irregular, tiradas en condiciones de lucha y represión, por lo que se ha primado el qué se dice y el cuánto se dice al dónde está situado en la publicación. Es preciso también apuntar que diferentes categorías pueden estar presentes en una misma unidad de análisis, como se ha constatado en la revisión de las publicaciones, pero se ha optado en estos casos por priorizar aquellas que presentan una mayor entidad en dicha unidad. En cuanto a la representación gráfica del análisis, se ha optado por reflejarlo en forma porcentual para poder evidenciar en términos proporcionales la importancia dada a cada concepto por parte del M26J y el DR.

\section{Movimiento 26 de Julio}

Los medios en los que se ha centrado el análisis en cuanto al M26J son Revolución y Sierra Maestra, dos de los órganos promovidos por el movimiento y tirados fundamentalmente desde el llano, es decir, sus responsables eran las células establecidas en las ciudades. Aunque el propósito de estas líneas no es realizar una historia de la prensa clandestina y guerrillera en Cuba, comentar que estos periódicos no serían los únicos publicados por el movimiento, si bien son los más representativos y los de mayor cuantía. Existen otras cabeceras que nacieron desde los parajes de la Sierra Maestra con el objetivo de trasladar el ideario y las acciones entre la tropa y las gentes de la zona. Surco, El Cubano

\footnotetext{
${ }^{22}$ Ibarra, op. cit.

${ }^{23}$ Eudald Cortina Orero, «Comunicación y proceso revolucionario en El Salvador. La prensa clandestina en la configuración y desarrollo de las organizaciones insurgentes», Naveg@mérica. Revista electrónica de la Asociación Española de Americanistas, nº 9, 2012.

${ }^{24}$ Véase la metodología clásica de análisis de prensa: Jacques Kayser, El periódico: estudios de morfología de metodología y de prensa comparada, Quito, CIESPAL, 1966.
} 
Libre, Patria y Milicianos fueron los títulos de estas publicaciones, producidas en precarias condiciones pero con el objetivo propagandístico como bandera ${ }^{25}$. Asimismo no se puede dejar de mencionar Radio Rebelde, un medio de comunicación clandestino, promocionado desde la guerrilla en la Sierra Maestra, que cumplió diversas funciones durante la lucha insurreccional, tales como informar y denunciar o servir de nexo de unión entre la sierra y el llano e incluso el extranjero ${ }^{26}$.

\section{Revolución}

Salió Revolución: informador, organizador, orientador, con una tirada de veinte mil ejemplares, anunciando que Fidel estaba vivo y en la Sierra Maestra, con la guerrilla y las milicias campesinas; jugó un papel importante en aquel momento de confusión, derrota y dificultades. Hizo viva la presencia del Movimiento en todo el país. Y la persecución policíaca se hizo implacable ${ }^{27}$.

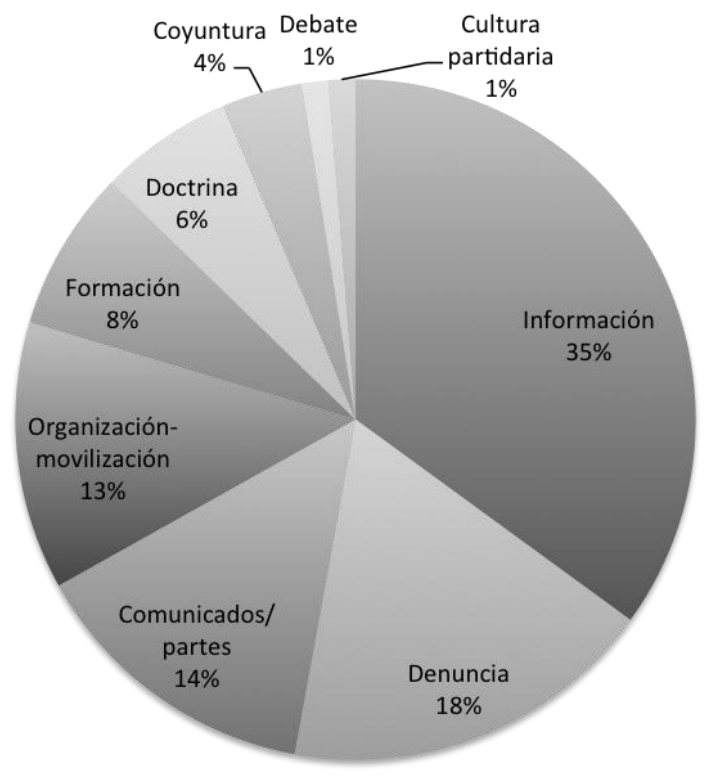

Figura 1. Categorías contenidas en Revolución 1957-1958.

Elaboración propia

\footnotetext{
${ }^{25}$ Vázquez, et. al., Apuntes de la prensa clandestina y guerrillera, 1952-1958, La Habana, UPEC, 1970; Montané Oropesa, «Apuntes sobre la prensa clandestina en Cuba», Granma, 08/09/1988, 4.

${ }^{26}$ Patricia Calvo González, La Sierra Maestra en las rotativas. El papel de la dimensión pública en la etapa insurreccional cubana, Tesis doctoral, Universidad de Santiago de Compostela, 2014b, 204-212. Véase también Ricardo Martínez Victores, 7RR. La historia de radio rebelde, La Habana, Ed. Ciencias Sociales, 1978.

${ }^{27}$ Franqui, op. cit., 183.
} 
El análisis de contenido de Revolución se ha realizado en base a 22 números, de los cuales 8 fueron tirados en 1957 y 14 en $1958^{28}$. En una dimensión general, este tipo de publicaciones asumen un carácter agitativo y orientador para la acción, así como una función de organizador colectivo ${ }^{29}$. No obstante, el estudio de Revolución evidencia que su principal función era la de informar seguida de la de denunciar (véase figura 1). La principal razón es que la publicación renace ${ }^{30}$ con el ánimo de dar a conocer a la opinión pública lo que estaba sucediendo en la isla, en un primer momento por los confusos mensajes que enviaba la prensa generalista (como por ejemplo, la muerte de Fidel Castro tras el desembarco del Granma $)^{31}$ y, posteriormente, por la censura que se establecería en el país ${ }^{32}$. Precisamente, desde el primer número se observa la intención anteriormente expresada de informar acerca de la existencia de una lucha sobre la que pesaban numerosos interrogantes. De esta manera, a lo largo de los dos años de lucha, las páginas del periódico se llenaron esencialmente de hechos noticiosos respeto de las acciones que realizaba el M26J, tanto en la sierra como en el llano, una función informativa que ocupó alrededor del $35 \%$ de la atención (véase figura 1). Y si esto lo sumamos a los conceptos de denuncia y de partes de las batallas, tenemos que la tirada dedica más de la mitad de su contenido a comunicar la realidad censurada en otro tipo de medios.

La juventud, con Fidel a la cabeza, se alza sobre la sangre y el sacrificio de sus mártires con mambisa altivez. De nuevo la manigua acoge amorosa las ansias libertadoras del espíritu redentor del 68 y del 95. Desde hace más de cuatro meses se escriben en la Sierra Maestra las más hermosas páginas de nuestra historia republicana, a pesar de todos los cálculos fatalistas de los estrategas militares, que auguraban la imposibilidad de este tipo de guerrillas en contra de los modernísimos armamentos que se supone respaldan al tirano [...] La propaganda regimental, en ridículo alarde, se esfuerza en decir que los rebeldes no están en la Sierra, pero lo que tiene de cierto esta versión es cuando se entiende que no sólo la Sierra, sino toda la Isla, es un hervidero de rebeldía y repulsa absoluta contra la dictadura batistiana $^{33}$.

Como se puede observar, está presente desde las primeras líneas una construcción ontológica entre el bien y el mal, que caracterizaría el discurso mediático del M26J. De hecho, la mayor parte de las columnas dedicadas a la denuncia hacían referencia, no sólo a

\footnotetext{
${ }^{28}$ La consulta de Revolución se realizó en la Oficina de Asunto Históricos del Consejo de Estado (La Habana, Cuba), donde se encuentra la totalidad de los números analizados. En el primer año, el tiraje termina en septiembre, existiendo ejemplares en los meses de febrero (3), mayo (1), junio (1), agosto (2) y septiembre (1). En 1958 existe un parón de febrero a mayo, teniendo así en enero (1), junio (3), julio (2), agosto (2), septiembre (1), octubre (2), noviembre (2) y diciembre (1).

${ }^{29}$ Cortina Orero, op. cit., 9 .

${ }^{30}$ Hablamos de renacer porque en los años anteriores existieron Son los Mismos, El Acusador y Aldabonazo, publicaciones que antecedieron a Revolución, con denominaciones cambiantes para adaptarlas al devenir de los acontecimientos. Véase Vázquez et. al., op. cit.

${ }^{31}$ Diario de la Marina, «Reitera la United Press que Fidel Castro pereció junto con su Estado Mayor poco después de desembarcar en Niquero», 4 de diciembre de 1956, 1.

${ }^{32}$ Calvo González, op. cit. 2014a.

${ }^{33}$ Revolución, «Editorial. Cuba y la Revolución», segunda quincena de febrero de 1957, 1.
} 
Batista (o al «tirano», como se le solía calificar), sino a individuos concretos de su gobierno y de su ejército, tachándolos de «asesinos» y aportando datos concretos de sus delitos ${ }^{34}$. Las acusaciones se extendían también a realidades concretas, como impedir la celebración de lo que ellos llamaban «la farsa electoral», comicios con los que Batista quería «legalizar»su presidencia, a celebrar el 3 de noviembre de $1958^{35}$. Relacionado con esto último, entraríamos en la función organizativo-movilizadora, que queda reflejada de manera explícita en forma de consignas. Con ellas incitaban a realizar acciones concretas en contra del gobierno, como quemar la caña o sabotear en las ciudades ${ }^{36}$. Las consignas se expresaron desde los primeros compases de la tarea propagandística y con unos objetivos muy concretos. La intención era hacer penetrar la información en determinados círculos sensibles a la causa, para después poder extenderlo al resto de la sociedad, dinámica que Domenach denomina «unanimidad y contagio» ${ }^{37}$. De este modo, mensajes como «brinda tu casa a los perseguidos»o «no compres la prensa censurada ${ }^{38}$ reflejan instrucciones de seguimientos no solo para militantes sino para todos los cubanos. De igual forma, estas consignas no se limitaban únicamente a estar incluidas en mensajes escritos, sino que la mayor parte de las veces se subrayaba su fuerza con ilustraciones que indicaban de forma precisa la intención buscada ${ }^{39}$.

En referencia al concepto de debate, sólo está contenido de manera clara en los números del año 1957. En ellos existen unos pocos artículos donde se extiende la polémica instalada en la vida política cubana entre resistencia cívica o solución armada, de la que los medios generalistas se hacían eco ${ }^{40}$. El M26J se expresa en este sentido favorable a mantener su lucha hasta encontrar una salida aglutinadora de la mayoría ${ }^{41}$. Dentro de la categoría de partes, se han incluido todas aquellas informaciones provenientes de la Sierra

\footnotetext{
${ }^{34}$ Revolución, «¡Asesino!», primera quincena de agosto de 1957, 14; «¡Asesino! 58 víctimas», septiembre de $1957,10$.

${ }^{35}$ Revolución, «Impidamos la farsa electoral», 14 julio 1958, 2.

36 «1.Quemar la caña, principalmente la de las grandes compañías nacionales y extranjeras (recuerden que si se le pega fuego a favor del viento, arde mejor); 2.Sabotear en las ciudades, industrias, comercios, servicios públicos, siempre los más grandes e importantes y los que sean propiedad de Batista o de gente del régimen, militares o civiles; 3.Organizar grupos de sanciones, para aplicar penas severísimas a los que entorpezcan el proceso revolucionario, cometan crímenes, torturen o chivateen; 4.Planificación. El sabotaje debe ser bien planeado y organizado con vista a destruir la base económica y política de la dictadura y provocar su caída. No debe afectar a los pequeños negocios, y se deben evitar las víctimas inocentes; 5.Organización. Los responsables deben apelar a la cooperación de los compañeros de su sector, haciéndoles ver la responsabilidad en el presente proceso histórico; 6.Economía. Continúese la recaudación económica, ahora más que nunca; 7.Propaganda. Repártase, reprodúzcase y diríjase la propaganda, haciéndola penetrar a los sindicatos, centros estudiantiles y mercantiles, etc.; 8.Células obreras y campesinas. Hágase funcionar con celo las células obreras y campesinas y désele gran atención al trabajo de penetración y proselitismo entre los trabajadores, los campesinos y los sectores progresistas del país». Revolución, «Tareas para los del 26», 2a quincena febrero 1957, contraportada.

${ }^{37}$ Jean-Marie Domenach, A propaganda política, Amadora, Livraria Bertrand, 1975.

${ }^{38}$ Revolución, enero 1958, 2.

${ }^{39}$ Revolución, «Con Batista no habrá zafra», septiembre 1957, 4.

${ }^{40}$ Bohemia, «¿Son las elecciones el camino para la paz?», nº6, febrero 1958, 75; o «Balas o votos. El pueblo no puede ser espectador en el drama cubano», $\mathrm{n}^{\circ} 8$, febrero 1958, 51.

${ }^{41}$ Revolución, «Solución sí, componenda no», $2^{\mathrm{a}}$ quincena febrero 1957, 2; «Los electoralistas fracasan», $1^{\mathrm{a}}$ quincena agosto $1957,10$.
} 
Maestra $^{42}$, en las que se explican de forma detallada el desarrollo de los combates ${ }^{43}$. Lo destacado en estos comunicados es que solían ir acompañados con imágenes ilustrativas de la vida en la guerrilla. Dicha práctica se convierte en el indicativo de que la construcción de la imagen revolucionaria en torno al Ejército Rebelde no fue cimentada únicamente por la prensa foránea ${ }^{44}$. El movimiento urbano de La Habana, encargado de la edición de Revolución, otorgaba así en sus páginas una mayor visualización a los hombres de la Sierra Maestra desde el punto y hora que sus acciones se apoyaban siempre en referentes gráficos. La información y la denuncia son, por tanto, los pilares sobre los que se asienta Revolución, ya que, como se ha visto, ambos conceptos suponen más del cincuenta por ciento del contenido del periódico. Si a esto sumamos los partes, se puede afirmar que casi tres cuartas partes de la publicación están dedicadas a hacer saber a la población lo que los medios generalistas callaban.

\section{Sierra Maestra}

¿Por qué este boletín semanal del 26 de Julio se llama «Sierra Maestra»? Su nombre no ha sido escogido al azar, ni por casualidad. Por el contrario, obedece a un propósito simbólico y efectivo. Hoy, en las serranías de Oriente se libra la guerra por la libertad de $\mathrm{Cuba}^{45}$.

Como se ha visto, Revolución constituyó el órgano nacional del grupo, así que Sierra Maestra se configuró como la publicación provincial, es decir, un boletín clandestino que se editaba de forma descentralizada en las diferentes provincias de la Cuba de la década de los cincuenta, con distinto contenido y fecha de publicación, pero bajo los mimos objetivos y una cabecera unificadora. El acicate del origen de esta publicación fue, al igual que el del citado órgano nacional, la supuesta muerte de Fidel Castro tras el desembarco del Granma ${ }^{46}$. De todos modos, estamos ante una publicación de tirada más irregular, sin una periodización concreta (a pesar de que se describa como «semanal» en la cita anteriormente referida), en el que muchos casos se limitan a un folio mecanografiado, donde se concentra la información o las consignas que el movimiento quería hacer públicas.

Las noticias que aparecían en el boletín se recibían por diferentes vías. La principal fuente de información era Radio Rebelde, de donde se obtenían los datos de forma directa acerca de las fuerzas irregulares desde el lugar de la acción, ya que este medio era un órgano propio de la guerrilla sita en las montañas orientales ${ }^{47}$. Otras informaciones llegaban a través de cables de las agencias de noticias que, debido a la censura de prensa que se

\footnotetext{
${ }^{42}$ En los ejemplares de 1958, los partes se incluían bajo el cintillo «Desde el frente».

${ }^{43}$ Revolución, «De México a la Sierra Maestra», $2^{a}$ quincena febrero 1957, 1; «La toma de La Plata y La emboscada de Palma Mocha», $2^{a}$ quincena febrero 1957, 2; «Victoria del ejército revolucionario en El Uvero», $2^{a}$ quincena junio 1957, 1; «La Guerra en la Sierra. Atacados: Estrada Palma, Bueyecito, Minas y San Pablo de Yao», $1^{a}$ quincena agosto 1957, 16; «Desde el frente de combate», septiembre 1957, 4-5.

${ }^{44}$ Calvo González, op. cit., 2014 b.

45 Sierra Maestra La Habana, 26 abril 1957, 1.

${ }^{46}$ En un principio, la publicación salió con el nombre de Boletín Informativo. Posteriormente se cambió a Últimas Noticias y finalmente se editaría bajo el título de Sierra Maestra. Vázquez et. al., op. cit.

${ }^{47}$ Martínez Victores, op.cit.
} 
había establecido en Cuba, no se publicaban en los medios generalistas y que eran suministrados por los miembros del M26J que trabajaban en los periódicos. Todo este trajín informativo de carácter clandestino estaba centralizado en el frente de propaganda, quien en última instancia suministraba el material, orientaba lo que se iba a publicar y revisaba el periódico una vez terminado ${ }^{48}$.

El análisis de contenido de Sierra Maestra se hizo a partir de 93 números, de los cuales 27 pertenecen a 1957 y 66 al año 1958. Esta inicial contabilización refleja el creciente interés por publicar el acontecer del grupo a medida que iba avanzando la contienda. Asimismo, la característica provincial del periódico lleva a otra reflexión preliminar. Como se puede ver en la figura 2, las seis provincias en las que se dividía Cuba en la década de los cincuenta contaban con una edición propia de Sierra Maestra. No obstante, en términos numéricos, los resultados son abrumadoramente desiguales. Tenemos así que, durante 1957, la provincia más prolífica fue la de La Habana y en el segundo año, la mayor cantidad de números tirados correspondió a Oriente. Así, esta representación aritmética reverbera un dibujo de la concentración de la acción durante la época final de la etapa insurreccional. Vemos como en el primer año, La Habana es la principal facilitadora de información, en un 1957 que se caracteriza por la reorganización de la estrategia tras el desembarco y en el que el aparato propagandístico empezaba a tomar forma. Conforme avanza el conflicto, se refleja como la acción se traslada hasta la parte oriental de la isla y, a medida que la guerrilla abandona las montañas para avanzar sobre las ciudades, los números en las provincias que entremedian entre la capital y Oriente aumentan.

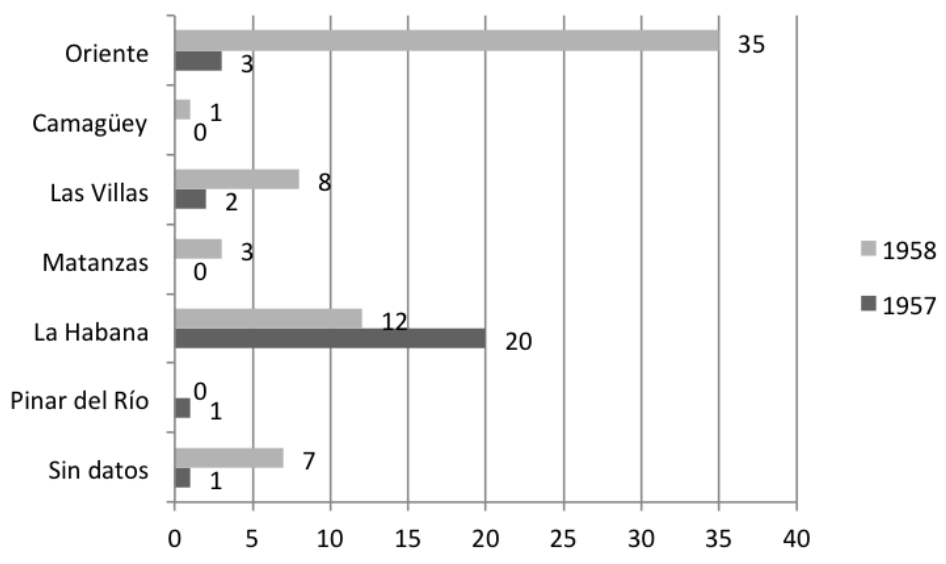

Figura 2. Números de Sierra Maestra por provincia y año de edición. Elaboración propia

Ciñéndonos a las jerarquías de análisis del contenido presentes en Sierra Maestra, vemos en general que los porcentajes no difieren demasiado de lo expuesto para el órgano nacional Revolución. La vocación, por tanto, de este boletín era mayormente informativa, seguida por la denuncia y el carácter organizativo-movilizador, como refleja la figura 3. Nos encontramos de nuevo ante una prensa clandestina en la que el ánimo doctrinal se relega a un segundo plano en pos de una mayor oferta noticiosa. El motivo viene dado por

${ }^{48}$ Vázquez et. al., op. cit., 50. 
tratarse de una publicación no restringida a la militancia y concebida para un público generalista: «Sierra Maestra llegará todas las semanas a las manos ávidas de militantes, simpatizantes y ciudadanos como un constante acicate para seguir en la brega» ${ }^{49}$.

Las inserciones de carácter informativo en Sierra Maestra versaban tanto de las acciones de sabotaje realizadas en las ciudades ${ }^{50}$, como de los acontecimientos que se desarrollaban en las montañas orientales ${ }^{51}$. Conforme avanzó el año 1958, el contenido de estas informaciones pasa de estar mayoritariamente brindado a las acciones urbanas, para ofrecer más datos acerca del acontecer de la guerrilla, presumiblemente por tres razones: 1) el incremento de la represión en las urbes tras el fracaso de la huelga de abril, lo que mermó la infraestructura clandestina metropolitana; 2) por la asunción del mando del movimiento por parte de Fidel Castro; y 3) por la ofensiva desplegada por Batista en la durante el verano de ese año, cuando la guerrilla tuvo más enfrentamientos directos con el ejército regular $^{52}$. Relacionado con esta cuestión, está el hecho de que en el segundo año de la publicación, la función que casi dobla su cifra es la que se refiere a los comunicados/partes. Este incremento se entiende respecto del lugar de edición de los números del periódico en 1958, que como se ha visto sobresale de forma notable la provincia de Oriente.

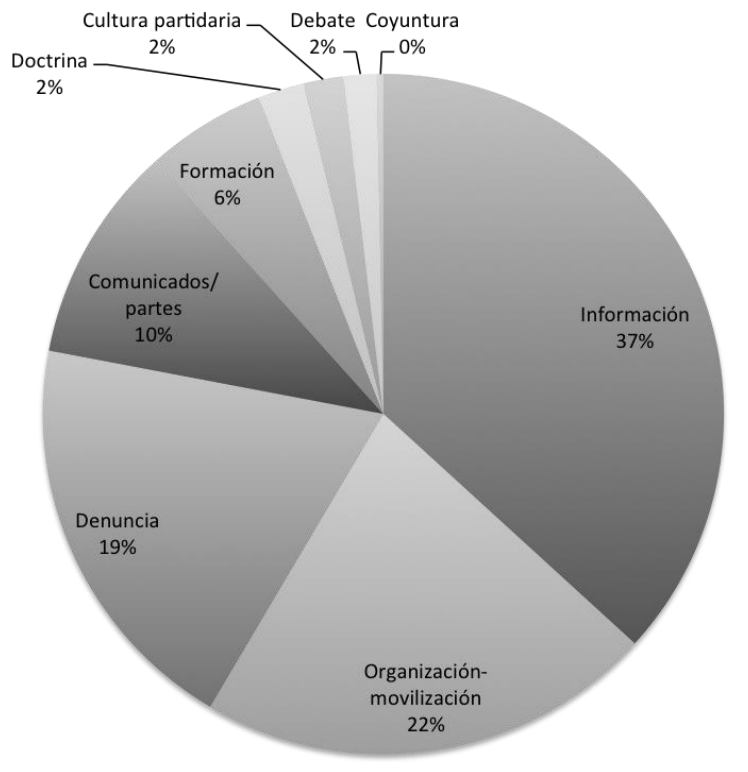

Figura 3. Categorías contenidas en Sierra Maestra 1957-1958. Elaboración propia.

\footnotetext{
49 Sierra Maestra La Habana, 26 abril 1957, 1.

${ }^{50}$ Sierra Maestra, 24 noviembre 1957, 4.

${ }^{51}$ Sierra Maestra, «Noticias de la Sierra», 7 septiembre 1957, 3.

52 Véase Sierra Maestra Oriente, «Reportaje sobre el combate sostenido por Fidel Castro y tropas gobiernistas en el encuentro de Pino del Agua», 8 marzo 1958, 4-5; Sierra Maestra Oriente, 18 junio 1958; Sierra Maestra Oriente, «Por los frentes», 31 agosto 1958, 4.; o Sierra Maestra Oriente, «Se rinden a los rebeldes soldados de la dictadura en Alto Songo», 15 noviembre 1958, 1.
} 
En cuanto a las denuncias, en esta ocasión no eran tanto dirigidas a las acciones de tipos en concreto, como en el caso de Revolución, sino que hacían referencia a cuestiones más generales, como las elecciones a celebrar en noviembre de $1958^{53}$, la compra de armas por parte de Batista a Inglaterra ${ }^{54}$, las preparación de «posibles agresiones» contra Cuba en la embajada de Estados Unidos ${ }^{55}$ o la situación de la prensa en el país: «Tócanos hoy abordar [...] el grave problema de la prensa nacional [...] la empresa corrompida, con la bolsa repleta, que responde a conveniencias de magnates poderosos y se inclina reverente ante el Gobierno de turno» ${ }^{56}$.

La función organizativa-movilizadora tiene una mayor cabida en las páginas de Sierra Maestra en comparación con Revolución (un 22\% y un 13\% respectivamente). Esta diferencia porcentual puede entenderse en función de la periodicidad de las publicaciones (semanal frente a quincenal/mensual), lo que hacía que el menor tiempo de elaboración para la tirada de Sierra Maestra sirviera para ofrecer instrucciones más inmediatas en forma de consignas.

\author{
Consignas a los del 26 \\ comunicación \\ - Campesinos: Quemar la caña e interrumpir las vías de \\ - Obreros: Organizar células en los centros de trabajo. Preparar \\ huelga general \\ - $\quad$ Mujeres: Bridar sus casas, levantar fondos, socorrer heridos \\ - Estudiantes y jóvenes: Fortificar las brigadas juveniles. Repartir \\ propaganda. Realizar sabotajes cuidando de no perjudicar inocentes. \\ pida en manifestación de protesta $^{57}$
}

Aunque las cuestiones doctrinales y de cultura partidaria eran de carácter residual en las páginas de Sierra Maestra, destacan algunas notas a tener en cuenta para ahondar en la conformación ideológica del grupo ${ }^{58}$. En los números de 1957 sobresalen las referencias al texto «Nuestra razón», el manifiesto de treinta y dos páginas del movimiento escrito por Mario Llerena en el que se apela a José Martí como fuente ideológica del M26J ${ }^{59}$.

\footnotetext{
${ }^{53}$ Sierra Maestra Las Villas, «Contra la farsa electoral», 28 octubre 1958, 1.

${ }^{54}$ Sierra Maestra Oriente, «Trata el dictador cubano de comprar equipo bélico a Inglaterra», 9 octubre 1958, 8.

${ }^{55}$ Sierra Maestra Oriente, «Denuncia Fidel Castro las posibles agresiones que contra Cuba se preparan en la embajada de los E.U.», 30 octubre 1958, 1.

56 Sierra Maestra La Habana, «Tentáculos», 14 julio 1957, 2.

57 Sierra Maestra La Habana, «Consignas a los del 26», 26 abril 1957, 1.

${ }^{58}$ Las cuestiones ideológicas y discursivas del M26J han sido revisadas por algunos autores en base a fuentes primarias (manifiestos, discursos y cartas, esencialmente). Véase Hugo Cancino, «El discurso ideológico de la Revolución Cubana. Para un estudio de las raíces histórico-ideológicas de la revolución», Història: Debates e Tendências, v. 10, n. 1, enero-junio, 2010. 73-86; Martín López-Ávalos, «La cultura política de la vanguardia o la construcción del ethos revolucionario. Cuba 1952-1959», Tzintzun. Revista de Estudios Históricos, Universidad Michoacana de San Nicolás de Hidalgo Morelia, México, núm. 53, enero-junio, 2011, 75-105.

${ }^{59}$ Mario Llerena, The Unsuspected Revolution: The Birth and Rise of Castroism, Londres, Cornell University Press, 1978. Durante los años de lucha, Mario Llerena ocuparía el cargo de presidente del Comité en el Exilio
} 
[...] era necesario recoger, en alguna forma de manifiesto programático, esas razones martianas del pasado para enfrentarlas, con letra viva, al dramático presente de Cuba. No pretende el trabajo, «Nuestra razón», ser definitivo, ni agotar, por supuesto, todos los aspectos y detalles de una futura política de gobierno. Pero si quedan centrada en él las directrices generales de nuestra lucha y los objetivos básicos de la Revolución ${ }^{60}$.

En el segundo año de la publicación, las referencias ideológicas se concentraron alrededor de tres asuntos: 1) el subrayado de los puntos doctrinarios presentes en la carta elaborada por Fidel Castro en contra del Pacto de Miami ${ }^{61}$; 2) los principales acuerdos del manifiesto del M26J del 12 de marzo $^{62}$; y 3) la carta a los militantes ${ }^{63}$. Los dos primeros artículos siguen la línea de expresar el carácter democrático de la lucha y que ninguna solución sería posible si no se plegaban a sus exigencias. Respecto del tercer punto, en la carta se reflexiona acerca de que «el diario combate no deja mucho tiempo para estas actividades espirituales tan necesarias», incidiendo en que la suya es una «misión histórica» para que se instale en el país un gobierno civil elegido de forma democrática.

Sierra Maestra se configura entonces como un instrumento de propaganda en la línea de lo planteado para el órgano nacional, cuya misión más destacada era la de sacar a la luz las noticias de las que la prensa generalista no se podía hacer eco. Una vez más, a pesar de divulgar las acciones que se llevaban a cabo en las ciudades, el hacer de la guerrilla ocupa un lugar destacado, sobre todo en 1958. Al igual que en Revolución, Sierra Maestra es un boletín editado desde las secciones de propaganda del llano en el que se destacan las acciones de las montañas.

\section{Directorio Revolucionario}

El Directorio Revolucionario surge oficialmente a inicios de 1955 como brazo armado de la Federación Estudiantil Universitaria (FEU). Toma su nombre en base a la historia del propio movimiento estudiantil, ya que a principios de la década de los treinta existió el Directorio Estudiantil Revolucionario en la lucha contra Gerardo Machado ${ }^{64}$. En la etapa insurreccional de los cincuenta, se optó por prescindir de la palabra «estudiantil» porque «debía estar integrado no solo por estudiantes, sino darle cabida a trabajadores,

del M26J, sito en Nueva York. Después del triunfo, disintió del rumbo que tomó la causa. El manifiesto de su autoría, «Nuestra razón», fue publicado en México en junio de 1957, pero en su primera edición se fechaba en noviembre de 1956 en Cuba por dos razones: para hacer ver que era fruto de discusiones mantenidas dentro del país y porque Llerena consideraba que había que mostrar que las acciones del M26J respondían a una filosofía política concreta. Bonachea y San Martín, op. cit., 156.

${ }^{60}$ Sierra Maestra, 7 septiembre 1957, 10. En el mismo texto se hace referencia al contenido del manifiesto, constando de una primera parte justificadora de la lucha armada («la guerra necesaria») y una segunda de carácter doctrinal donde se alude a la soberanía nacional y a la independencia económica.

${ }^{61}$ Sierra Maestra Oriente, «Puntos doctrinarios de la carta de Fidel Castro», 27 enero 1958, 2 y 4. Respecto del Pacto de Miami, véase Thomas, op. cit., 1245-1250.

${ }^{62}$ Sierra Maestra, «El manifiesto del 26 de Julio», suplemento 19 marzo 1958, 1 y 3.

${ }^{63}$ Sierra Maestra, 17 agosto 1958, 1.

${ }^{64}$ Raúl Roa, Retorno a la Alborada, Las Villas (Cuba), Universidad Las Villas, 1964. 
empleados, profesionales y a todos aquellos revolucionarios que se vinculaban en la lucha a la Universidad» ${ }^{65}$. Pero antes de conformarse como grupo armado, la FEU y la Universidad de La Habana jugaron un papel fundamental en la vida política cubana como promotores de las primeras movilizaciones en contra del golpe de estado de Batista (10 de marzo de 1952). Fue en estas fechas cuando empezaron a publicar de nuevo Alma Mater, órgano que por establecer consignas en contra del gobierno se vuelve de carácter clandestino. La otra publicación de relevancia del grupo fue el Boletín 13 de Marzo, que aunque no resultó demasiado prolífica (12 ejemplares tan solo), sus contenidos revelan aspectos fundamentales del DR.

El DR tuvo un antes y un después tras el 13 de marzo de 1957 (fecha en la que asaltaron el Palacio Presidencial) en cuanto a estrategia y militancia. Inicialmente, el grupo se planteó la posibilidad de atacar y tomar las distintas fortalezas militares de La Habana, idea que desecharon por no encontrar viabilidad, además de que «podría dar la impresión de una asonada militar ajena al pueblo». De este modo, focalizaron esfuerzos en el proyecto del ataque y toma del Palacio Presidencial y, por extensión, el asesinato de Batista. Para el DR, allí estaba «la sede de la tiranía» y desde donde partían todos los hilos de la conducción del poder dictatorial. Asimismo, el palacio era también una fortaleza militar, por lo numeroso de su guarnición, lo cual proporcionaría una gran cantidad de armas, suficientes para continuar hacia otros objetivos que irían convirtiendo a La Habana en una gran sublevación popular. Los objetivos que se trazaron los miembros del DR el 13 de marzo de 1957 fueron tres: asalto al Palacio Presidencial, toma de una emisora (Radio Reloj) para difundir la voz del movimiento revolucionario y ocupación de la Universidad de La Habana como sede de su Estado Mayor. Los planes entonces se orientaban a dar la batalla en la capital y, en caso de éxito, tomar las medidas que garantizaran la toma del poder para el verdadero triunfo de la Revolución, no aceptando golpes de estado y obligando al Ejército a rendirse o incorporarse a los revolucionarios en la lucha de ciudad ${ }^{66}$.

En este plan, el líder del DR, José Antonio Echeverría, encabezó la toma de Radio Reloj, desde donde anunció la muerte de Batista antes de que cortaran la emisión. Desde allí se dirigió a la Universidad de La Habana, donde cayó abatido en un intercambio de disparos con una patrulla policial. En el ataque al Palacio, sólo un pequeño grupo pudo penetrar al edificio, pero los francotiradores de la guardia del último piso dominaron con fuego cerrado los pasillos. Los asaltantes llegaron incluso hasta el despacho de Batista, pero el presidente ya había huido. Al ver que era imposible seguir avanzando y percatarse de que el grupo de apoyo no estaba combatiendo, se decidió la retirada. Fue precisamente a este grupo de apoyo a quien en las páginas de su prensa culpan «únicamente» del fracaso del ataque, haciendo responsable al señor Ignacio González por tres razones:

1) Incapacidad en su actuación como Jefe; 2) Irresponsabilidad. No estaba listo con sus hombres y dio la orden de partir al primer comando diciendo que lo estaba; 3 )

\footnotetext{
${ }^{65}$ Ramón Pérez Cabrera, De Palacio hasta Las Villas. En la senda del triunfo, Buenos Aires, Nuestra América, 2007, 14.

${ }^{66}$ ONBAP, 13 documentos de la insurrección, La Habana, Organización Nacional de Bibliotecas Ambulantes y Populares, 1959, 53- 58.
} 
Cobardía. Llegó a las cercanías del Palacio con un camión lleno de armas y exponiendo un burdo pretexto, las abandonó ${ }^{67}$.

Tras el fracaso del asalto y la muerte de José Antonio Echeverría, Fructuoso Rodríguez asumió la Secretaría General del Directorio y junto a los compañeros supervivientes analizaron los hechos para recomponerse. Pero casi un mes más tarde, el 20 de abril de 1957, el DR sufrió otro golpe, conocido como los sucesos de Humboldt $\mathrm{n}^{\mathbf{0}}$ 7, dirección donde estaban reunidos miembros del grupo en La Habana. Allí fueron sorprendidos por la policía y acribillados. Las bajas y la represión policial hicieron replantearse toda la estrategia al grupo, que terminaría abriendo un frente guerrillero en la Sierra del Escambray, aunque siempre con el objetivo de «Golpear Arriba» por bandera ${ }^{68}$.

A pesar del activismo del DR en la lucha insurreccional, después de 1959, «mientras en los discursos iniciales aparecerían claramente la participación urbana y obrera así como el carácter anti dictatorial de la revolución, a partir de 1960 podría observarse una progresiva "serranización" de la experiencia revolucionaria» ${ }^{69}$. De este modo, se constata como en la lucha todos los frentes y grupos tuvieron su papel, pero en la reconstrucción histórica no se trasladó con el mismo equilibrio. Así las cosas, Child afirma que tras la victoria revolucionaria, la historiografía cubana ignoraría a propósito el importante papel que los grupos no fidelistas jugaron a la hora de hacer calar el ambiente revolucionario en todas las esferas sociales cubanas. El autor interpreta que el hecho de que se haya abordado la labor realizada por la resistencia urbana resaltando sus fracasos (ataque al Palacio Presidencial, huelga general) sirvió para «poner la carga de la revolución en los hombros de Fidel Castro», haciendo que la sierra emergiera como la líder revolucionaria de forma predeterminada ${ }^{70}$. Por este motivo resulta relevante ahondar en la prensa editada por los diferentes grupos opositores, ya que revelan los discursos y acciones de los mismos y completan el rompecabezas de una rebelión con muchos ganadores del que prácticamente solo se conoce uno.

\section{Alma Mater}

ALMA MATER vuelve a la trinchera para contribuir a la reconquista de las libertades holladas y de la tranquilidad perdida. Su programa es el programa de la Federación Estudiantil Universitaria. [...] Viene a unir, a vertebrar, a soldar las voluntades todas en un amplio y vigoroso frente de batalla civil contra la dictadura castrense de Fulgencio Batista. Esa es la premisa previa de la victoria. La pugna en que estamos empeñados solo puede ganarse mediante las movilizaciones del pueblo entero al margen de los sectarismos políticos y de los intereses de grupos ${ }^{71}$.

\footnotetext{
${ }^{67}$ Boletín 13 de Marzo, «Aclaración histórica del Directorio sobre el asalto al Palacio Presidencial», 1957.

${ }^{68}$ Boletín 13 de Marzo, «Del Escambray a La Habana», marzo 1958.

${ }^{69}$ Julieta Bartolleti, «Organizaciones armadas latinoamericanas: problemas y propuestas de análisis», Revista Pilquen, Sec. Ciencias Sociales, Año XIII, nº 14, 2011, 7.

${ }^{70}$ Matt D. Childs, «An historical critique of the emergence and evolution of Ernesto Che Guevara's Foco Theory», Journal of Latin American Studies, vol. 27, 1995, 593-624.

${ }^{71}$ Alma Mater, «Editorial: Otra vez en la calle», 12/04/1952, 3.
} 
En el caso del análisis de la prensa clandestina del DR, se han tomado sus dos publicaciones más representativas, que son Alma Mater y el Boletín 13 de Marzo. De Alma Mater, el análisis fue en base a 20 números entre 1952 y $1958^{72}$, y cuya finalidad principal era «destruir la propaganda oficial». La intención inicial era además tener una periodicidad quincenal, pero las dificultades para imprimir los números obligaban a sacar la publicación cuando se podía, característica bastante común a la prensa clandestina de cualquier signo o lugar, ya que por una parte se tiene que buscar cómo financiar la empresa y por otra se tiene que ver como tirar los periódicos sin ser descubiertos.

En referencia a la figura 4, donde aparecen representadas las jerarquías que predominaban en el periódico, muestra que más del sesenta por ciento de los contenidos están orientados a la información y a la denuncia, es decir, como en los casos anteriores respecto del M26J, a publicar lo que otros medios silenciaban. Se centra, sobre todo, en las acciones del grupo, así como en denunciar tanto contextos generales (la censura, por ejemplo ${ }^{73}$ ), como individuos concretos, empezando por Batista ${ }^{74}$ y llegando a jefes de las fuerzas armadas corruptos o que cometían asesinatos impunes ${ }^{75}$. Lo expuesto trasluce las prioridades de las bases del DR, es decir, la destrucción de la propaganda oficial pasaba por sacar a la luz todos los esfuerzos a nivel de movilización social o armada y asimismo dar a conocer las atrocidades que cometían individuos concretos del gobierno de Batista y de sus fuerzas de armadas y del orden, con el objetivo de hacer ver a la sociedad que no se velaba en Cuba por un bien general, sino que se iba en contra de la población.

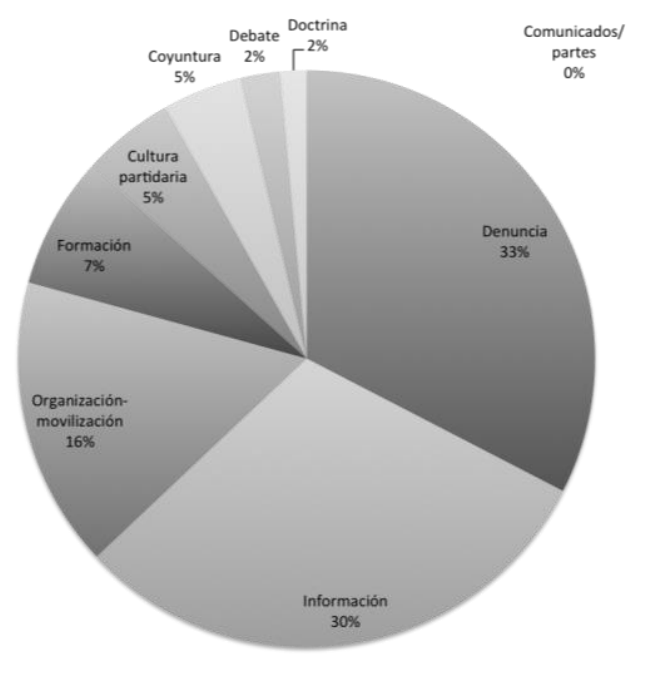

Figura 4. Categorías contenidas en Alma Mater 1952-1958. Elaboración propia

A diferencia de los órganos del M26J, es significativa la mayor presencia en las páginas de Alma Mater las referencias a los «mártires»: todas esas personas en la lucha en

723 ejemplares de 1952, 4 de 1953, 1 de 1955, 3 de 1956 y 9 de 1958.

${ }^{73}$ Alma Mater, «Un organismo totalitario», abril 1952.

${ }^{74}$ Alma Mater, «iBatista, la mano criminal!», febrero 1953.

${ }^{75}$ Alma Mater, «Torturas bestiales», abril 1952; «Asesinado por agentes de la Chiva Masferrer», julio 1958. 
contra del régimen que fueron asesinadas. Por una parte, se denuncia su muerte cruel e injusta y, por otra, se les rinde homenaje para que sirvan como ejemplo de la no rendición. En la línea de lo que expone Cortina Orero para el caso salvadoreño, «la representación de los caídos remite a un pasado de sacrificio, vinculando esos esfuerzos pasados, esa sangre derramada, con un futuro mejor por el que seguir combatiendo ${ }^{76}$. Los caídos tienen, por tanto, una presencia importante en la prensa clandestina de la FEU, con inserciones acerca de su vida o su pensamiento ${ }^{77}$, o con reconstrucciones precisas de cómo el régimen al que estaban combatiendo acababa con la vida de jóvenes valientes y luchadores ${ }^{78}$. Se vincula esta dinámica con lo expresado anteriormente acerca de las mayores vicisitudes sufridas por los grupos de naturaleza urbana que, aunque prácticamente silenciados históricamente, en la práctica fueron sometidos a una mayor vigilancia y represión y, ante el número de bajas, se entiende que corrieron mayores riesgos.

Respecto de la organización-movilización, las consignas en el órgano de la FEU no revelan una presencia mayoritaria, con un $16 \%$ del espacio ocupado. Estas se dirigían en esencia a tres frentes: al pueblo o ciudadanía en general, a los militares y a los obreros. Respecto de las orientadas al primer grupo, eran indicaciones de carácter general de actuación, para realizar acciones propagandísticas y de apoyo al movimiento ${ }^{79}$. Las directrices hacia los militares eran muy claras: que dejaran de luchar por el «tirano» y se unieran a la causa ${ }^{80}$. De similar índole eran las consignas hacia los obreros, a los que instaban a unirse al estudiantado y hacer un frente común de lucha, sobre todo de cara a la organización de la huelga general revolucionaria ${ }^{81}$.

Tenemos así un periódico de tirada irregular, que se reedita al poco del golpe de estado de Batista para vehicular la oposición frontal del estudiantado hacia el régimen impuesto. Aunque incidían en la movilización general de la ciudadanía en contra de Batista $^{82}$, sus páginas se llenan con noticias acerca de las acciones que llevaban a cabo,

\footnotetext{
${ }^{76}$ Cortina Orero, op. cit, 19.

${ }^{77}$ Alma Mater, «Este es el hombre que Batista asesinó», agosto 1952; «Nuestro Rubén Batista», marzo 1956; «Del testamento político de José Antonio Echeverría», 1958.

${ }^{78}$ Alma Mater, «Nuestros mártires nos guían», «Otro mártir, ¿cuántos más haremos falta», 1955; «Así cayó nuestro presidente», «Humboldt 7», abril 1958.

${ }^{79}$ Consigna ${ }^{\circ} 1$. Pueblo: Recibe y distribuye, con el cuidado necesario, toda nuestra propaganda de oposición al régimen. [...]. Consigna $\mathrm{n}^{\mathbf{0}}$ 2. Pueblo: No permanezcas indiferente ante los atropellos de los estudiantes y demás conciudadanos. Acumula trastos viejos en tu casa y lánzalos a la calle cuando ocurra otra agresión. [...]. Consigna $n^{o}$ 3. Ciudadano: Forma en tu fábrica, centro de estudio, oficina, taller de trabajo, colegio profesional o en donde puedas, un Comité de resistencia con tus amigos de confianza y con tus familiares. Sigan entonces las consignas del estudiantado. Consigna $n^{\circ}$ 5. Ciudadanos: No asistas a los cines que exhiban en sus pantallas el NOTICIERO NACIONAL. Te obligan a ver constantemente el rostro del Tirano. [...]. Alma Mater, «Consignas», 1955.

80 «Ahora es la oportunidad de que los soldados de la república cumplan con su deber de cubanos y no solo con el de partidarios de Batista [...]. El militar debe de ser hombre de honor y patriota, nunca puede hacer causa común con quien delinque y mucho menos con quien asesta un golpe mortal a la Nación». Alma Mater, «El principio del fin», abril 1958.

${ }^{81}$ Alma Mater, «La lucha del proletariado y del movimiento estudiantil», 1953; «Obrero únete a la causa», 1958.

${ }^{82}$ Alma Mater, «Declaración de principios», agosto 1952.
} 
denuncias de los desmanes de la oficialidad y glorificación de los mártires de la causa como símbolo de una lucha que había que llevar hasta el final.

\section{Boletín 13 de Marzo}

«La palabra es para decir la verdad, no para encubrirla», sentenció nuestro Apóstol. Para exponer verdades en un puñado de palabras, el DIRECTORIO REVOLUCIONARIO edita hoy esta pequeña y sencilla hoja, para irradiar al pueblo un poco de luz ante tanta tiniebla presente. [...] 13 de Marzo está pues en la calle, para denunciar las verdades que la dictadura quiere acallar; para orientar a un pueblo en la conquista de su Libertad ${ }^{83}$.

En el caso del Boletín 13 de Marzo, la tendencia es similar a la de Alma Mater, pero con matices, ya que existe un reparto más equitativo entre información, denuncia, organización-movilización, cultura partidaria y coyuntura, como se puede ver en la figura 5. Este equilibrio y el hecho de que, por ejemplo, aparezca la jerarquía de comunicados/partes que en Alma Mater no había, tiene su explicación inicial en que este boletín se empieza a tirar en el año 1957. El análisis se ha realizado en base a 12 números, el grueso del año 1958, y con algunos ejemplares tirados desde el exilio en Estados Unidos ${ }^{84}$. El acicate, una vez más, era sacar a la luz todo aquello que los medios convencionales tenían que silenciar a causa de la censura, combinado con denuncias, directrices de actuación y aspectos identitarios ${ }^{85}$.

Si en Alma Mater no existía la categoría de partes quiere decir, por un lado, que los objetivos de la publicación eran diferentes y consideraban que debía de ser el órgano del brazo armado quien difundiera este tipo de inserciones. Por otro lado, el DR abrió en 1958 un frente guerrillero en la Sierra del Escambray, estrategia que da lugar a la elaboración de partes y comunicados, al ser acciones que ocurren en zonas remotas y que tienen que ser reconstruidas y difundidas para hacerlas saber tanto al grupo como a la sociedad en general $^{86}$. Como se ha visto, en la prensa clandestina del M26J, los comunicados y partes ocupan un porcentaje mayor, ya que este grupo tiene una guerrilla rural en funcionamiento desde un año antes, y se encargaban de transmitir sus proezas en las diferentes publicaciones que tiraban.

El contenido de la información y denuncia del Boletín 13 de Marzo es similar al de Alma Mater, y también a la del M26J, ya que el objetivo era saltar el cerco informativo existente en Cuba, donde no se permitía informar acerca de las acciones de grupos armados, y menos si estas acciones tenían repercusiones negativas en el gobierno. De hecho, analizando la prensa cubana de la época, raramente se aprecia una situación irregular en Cuba, ya que eran muchos los periódicos que recibían prebendas del Gobierno, aparte de la

\footnotetext{
${ }^{83}$ Boletín 13 de Marzo, 1957.

${ }^{84}$ Dos ejemplares del año 1957, 8 de 1958 y 2 de 1959, dedicados estos últimos a la victoria.

${ }^{85}$ El DR contaba también con otras publicaciones, bajo el título Actualidad de Cuba y La Voz del Escambray. Véase Boletín 13 de Marzo, «Aviso importante», septiembre 1958.

${ }^{86}$ Boletín 13 de Marzo, «Escambray: Segundo Frente Nacional», junio 1958.
} 
censura instaurada. Por ejemplo, en el Diario de la Marina, se publicaban los partes de Ejército regular, y siempre informaban de bajas rebeldes o de su captura, no había referencia a los descalabros de la oficialidad. Y si a esto le sumamos otro tipo de noticias, en las que aparecía Batista hablando de bonanza económica o de grandes obras públicas, se puede llegar a pensar que en el país no estaba ocurriendo nada ${ }^{87}$.

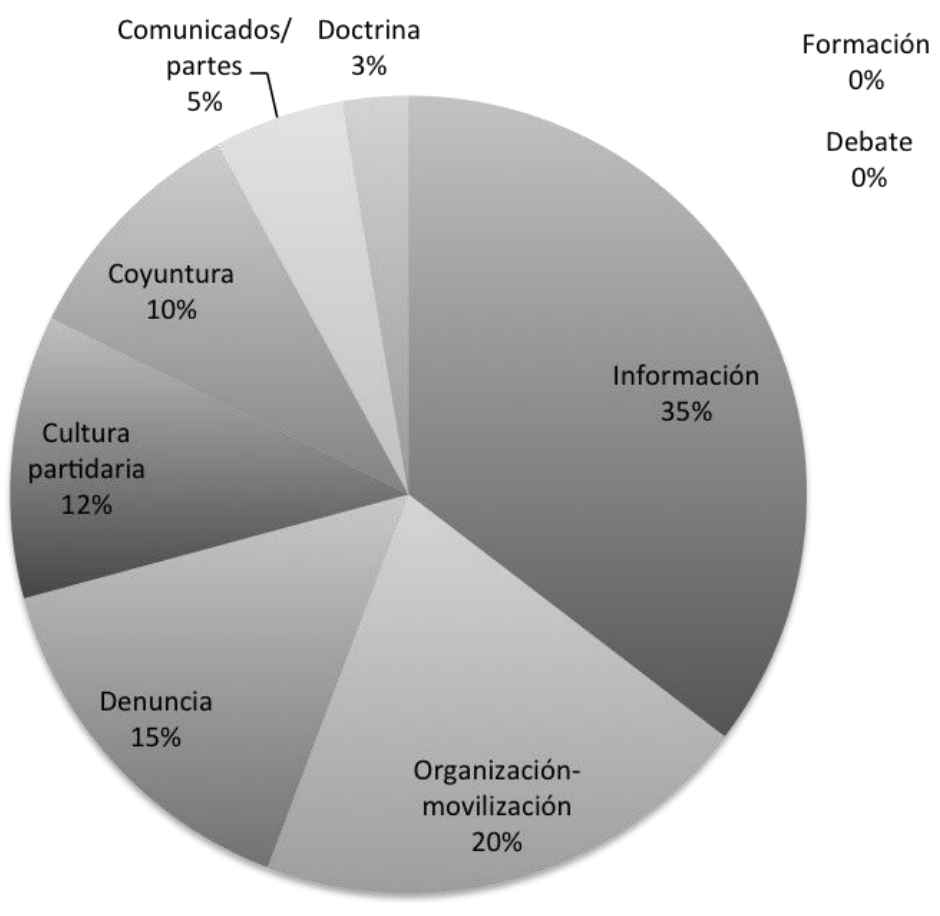

Figura 5. Categorías contenidas en Boletín 13 de Marzo 1957-1959. Elaboración propia

Pero volviendo a la prensa clandestina del DR, es reseñable el aumento porcentual en la jerarquía organización-movilización (del 16\% al 20\%). La consigna más repetida a lo largo del boletín del grupo era la de «Golpear Arriba», a la que solían adjuntar un listado de nombres a eliminar, encabezado por Fulgencio Batista ${ }^{88}$. Está también la cuestión de la unidad ante la convocatoria de huelga general, apelando especialmente a los estudiantes ${ }^{89}$, a los obreros ${ }^{90}$ y a los soldados a unirse a la misma ${ }^{91}$.

La cultura partidaria, sin ser mayoritaria, se revela en un mayor porcentaje en las páginas del Boletín 13 de Marzo que en la prensa del M26J. Esta queda reflejada fundamentalmente en una serie de artículos que versan sobre la necesidad de unión y de

\footnotetext{
${ }^{87}$ Calvo González, op. cit., 2014a.

${ }^{88}$ Boletín 13 de Marzo, 1957.

${ }^{89}$ «El estudiantado es la vanguardia de nuestra lucha». Boletín 13 de Marzo, marzo 1958.

90 «Trabajadores por libertad con justicia social únete a la huelga general». Boletín 13 de Marzo, marzo 1958.

91 «Rebélate militar cubano junto a la huelga general y la insurrección popular!». Boletín 13 de Marzo, marzo 1958.
} 
seguir adelante, a pesar de las derrotas sufridas, tanto en el ataque a Palacio como en los hechos de Humbolt $n^{\circ} 7$. En estas inserciones se plasmó un reforzamiento de la idea de continuar la lucha, glorificando no sólo a mártires concretos (como el propio José Antonio Echeverría), sino que las acciones fallidas tenían que servir para seguir adelante sin rendición. Se relaciona de nuevo con la apertura de un frente guerrillero rural, incidiendo en que es un complemento a su táctica inicial de «golpear arriba», pero dadas las circunstancias, tuvieron que diversificar su estrategia, tanto para conseguir «un 13 de marzo victorioso» como para garantizar la supervivencia de los miembros del grupo ${ }^{92}$. Se vinculan también estos aspectos identitarios y su mayor presencia en las páginas de la prensa del DR respecto del M26J a ese poso de derrota, a la necesidad de reinventarse y a la de reforzar la pertenencia al grupo, así como a la de diferenciarse de los otros movimientos opositores. Existen diversas inserciones que abogan por la «unión revolucionaria», es decir, aunar esfuerzos para que el objetivo común de derrocar a Batista se llevara a cabo. No obstante, quisieron marcar diferencias de actuación y de acciones, llegando a corregir informaciones que aparecían en la prensa del M26J:

Ataque al cuartel y toma de Guinia de Miranda, Las Villas, por fuerzas rebeldes del Directorio Revolucionario al mando del Comandante Rolando Cubela. [...] Queremos aclarar que en una información aparecida en el colega Revolución este combate se atribuye a fuerzas del 26 de Julio atribuyéndose ello a que dicha redacción no tenía los partes oficiales procedentes de Escambray ${ }^{93}$.

El Boletín 13 de Marzo, en definitiva, al igual que las publicaciones anteriormente analizadas, pretendía romper el cerco de la verdad oficial y de la censura, informando acerca de las acciones del grupo y denunciando situaciones que iban en contra de la pretendida democracia. No obstante, el desarrollo de los acontecimientos y la diferente naturaleza del grupo, de esencia mayoritariamente urbana hasta 1958, hizo que sus páginas se llenaran, al margen de las noticias, de semblanzas de los caídos y de refuerzo de la táctica del DR de «golpear arriba».

\section{Mismo objetivo, diferentes tácticas. A modo de conclusión}

Del estudio de los órganos editados por los grupos opositores más activos y con más presencia durante la etapa insurreccional de la década de los cincuenta en Cuba, se desprenden tres ideas esenciales. La primera, que se extrae directamente del análisis de la prensa clandestina, es que esta, en los dos grupos armados a analizar, es fundamentalmente de denuncia, información y movilización. Esto es indicativo de que la prioridad era derrocar el régimen, no importando tanto las cuestiones doctrinales o de ideología, característica similares tanto el M26J como el DR. Como se ha visto en las cuatro publicaciones analizadas, su finalidad era romper con la censura, sin dedicar un espacio relevante a los idearios de ambas organizaciones. Quizá el DR hace un poco más de

\footnotetext{
${ }_{92}$ Boletín 13 de Marzo, «Del Escambray a La Habana», marzo 1958.
}

${ }^{93}$ Boletín 13 de Marzo, septiembre 1958. 
hincapié en asuntos relacionados con aspectos partidarios, por esa necesidad de reinventarse y de propiciar la pertenencia a unas siglas que sufrieron serios reveses a lo largo de la etapa insurreccional. En definitiva, los órganos de ambos grupos ejercieron de informadores de lo que estaba ocurriendo y de movilizadores para derrocar a Batista. Es decir, compartieron objetivos.

En segundo lugar, a partir de este análisis, se constata que el papel del DR y de las facciones urbanas del M26J quedó diluido en la omnipresencia de la Sierra Maestra. Las diferentes tácticas de ambos grupos y su desarrollo otorgaron preeminencia a la guerrilla rural del M26J, entre otros factores, por la publicidad internacional dada al ejército rebelde liderado por Fidel Castro ${ }^{94}$. Histórica e historiográficamente, como se ha visto, el DR y los comandos urbanos de cualquier signo tienen un poso de derrota, al ser reconocidos por el frustrado ataque al Palacio Presidencial o por su activa participación en la fallida huelga general de abril de 1958, sin valorar otras acciones, como los sabotajes que se sucedieron durante toda la etapa a lo largo de la isla o su papel como inoculadores de las pretensiones revolucionarias en la sociedad cubana. En la prensa clandestina se observan inserciones en este sentido, plasmando la movilización que existió a lo largo y ancho de toda la isla, pero iconográficamente siempre se primaron las operaciones de la guerrilla rural, dejando otro tipo de maniobras en un segundo plano.

De esta cuestión deriva una tercera y definitiva reflexión: la historia de la guerrilla urbana en la insurrección cubana está por hacer. Fueron numerosos los grupos que participaron $\mathrm{y}$ en distintos puntos del país, con acciones que poco a poco fueron erosionando el régimen hasta el 1 de enero de 1959, pero de las que apenas se tiene constancia. La prensa clandestina serviría entonces como una fuente fundamental para la reconstrucción de esos hechos exiguamente mencionados y completar el puzle de un proceso que marcó un antes y un después en el desarrollo histórico de Cuba y su posicionamiento en la geopolítica internacional a partir de la década de los sesenta.

\section{Referencias}

\section{Documentos hemerógraficos}

Alma Mater, 1952-1958

Boletín 13 de Marzo, 1957-1959

Revolución, 1957-1958

Sierra Maestra, 1957-1958

\section{Bibliografía}

Bartolleti, Julieta, «Organizaciones armadas latinoamericanas: problemas y propuestas de análisis», Revista Pilquen, Sec. Ciencias Sociales, Año XIII, no 14, 2011.

Bonachea, Ramón y San Martín, Marta, The Cuban Insurrection, 1952-1959, New Jersey, Transaction Books, 1974.

\footnotetext{
${ }^{94}$ Calvo González, op. cit., 2014b.
} 
Calvo González, Patricia, «Visiones desde dentro. La insurrección cubana a través del Diario de la Marina y Bohemia (1956-1958)», História (São Paulo), v.33, n.2, jul./dic. 2014a.

Calvo González, Patricia, La Sierra Maestra en las rotativas. El papel de la dimensión pública en la etapa insurreccional cubana, Tesis doctoral, Universidad de Santiago de Compostela, 2014b.

Cancino, Hugo, «El discurso ideológico de la Revolución Cubana. Para un estudio de las raíces histórico-ideológicas de la revolución», Història: Debates e Tendências, v. 10, n. 1, enero-junio, 2010. 73-86.

Childs, Matt D., «An historical critique of the emergence and evolution of Ernesto Che Guevara's Foco Theory», Journal of Latin American Studies, vol. 27, 1995, pp. 593624.

Cortina Orero, Eudald, «Comunicación y proceso revolucionario en El Salvador. La prensa clandestina en la configuración y desarrollo de las organizaciones insurgentes», Naveg@mérica. Revista electrónica de la Asociación Española de Americanistas, no 9 , 2012.

Domenach, Jean-Marie A propaganda política, Livraria Bertrand, Amadora, 1975.

Franqui, Carlos, Diario de la Revolución Cubana, Barcelona, Ediciones R. Torres, 1976.

Ibarra, Pedro, «La prensa clandestina en Euskadi bajo el franquismo», La prensa de los siglos XIX y XX. Metodología, ideología e información. Aspectos económicos y tecnológicos, Bilbao, Universidad del País Vasco, 1986.

Ibarra Guitart, Jorge Renato, El fracaso de los moderados en Cuba. Las alternativas reformistas de 1957 a 1958, La Habana, Editora Política, 2000.

Llerena, Mario, The Unsuspected Revolution: The Birth and Rise of Castroism, Londres, Cornell University Press, 1978.

López-Ávalos, Martín, «La cultura política de la vanguardia o la construcción del ethos revolucionario. Cuba 1952-1959», Tzintzun. Revista de Estudios Históricos, Universidad Michoacana de San Nicolás de Hidalgo Morelia, México, núm. 53, enerojunio, 2011, 75-105.

Martínez Victores, Ricardo, 7RR. La historia de radio rebelde, La Habana, Ed. Ciencias Sociales, 1978.

ONBAP, 13 documentos de la insurrección, La Habana, Organización Nacional de Bibliotecas Ambulantes y Populares, 1959.

Pérez Cabrera, Ramón, De Palacio hasta Las Villas. En la senda del triunfo, Buenos Aires, Nuestra América, 2007.

Pérez Rivero, Roberto, La guerra de liberación nacional, Santiago de Cuba, Ed. Oriente, 2006

Pérez-Stable, Marifeli, La revolución cubana. Orígenes, desarrollo y legado, Madrid, Colibrí, 1998.

Pineda Cachero, Antonio, "Orígenes histórico-conceptuales de la teoría de la propaganda nazi», Revista Historia y Comunicación Social, $\mathrm{n}^{\circ}$ 12, 2007.

Pizarroso Quintero, Alejandro, Historia de la propaganda. Notas para un estudio de la propaganda política y de guerra. Universidad Complutense de Madrid, 1993.

Pizarroso Quintero, Alejandro, «La historia de la propaganda: una aproximación metodológica», Historia y Comunicación Social, n 4, 1999.

Roa, Raúl, Retorno a la Alborada, Las Villas (Cuba), Dirección Publicaciones Universidad Las Villas, 1964. 
Schulze, Ingrid, El poder de la propaganda en las guerras del siglo XIX, Madrid, Arco Libros, 2001.

Thomas, Hugh, Cuba. La lucha por la libertad, Barcelona, Grijalbo, 1974.

Vázquez, et. al., Apuntes de la prensa clandestina y guerrillera, 1952-1958, La Habana, UPEC, 1970.

Zanetti, Óscar, Historia mínima de Cuba, México, El Colegio de México, 2013. 